\title{
International Migration and Containment Policies: Lessons from Libya ${ }^{1}$
}

\begin{abstract}
The author argues in this study that over the past three decades Libya has been a true laboratory for European and especially Italian migration policies. The years from the 1990s until the present have been characterised by two conflicting tendencies in Libya: on the one hand, the policies of the Qadhafi regime, characterised by an open-door policy towards the influx of low-cost labour from sub-Saharan Africa and the Arab countries; on the other hand, the containment policies put in place by Italy to halt illegal migration flows through the Mediterranean Sea, which were however an infinitely small proportion of the total number of migrants in Libya. Therefore, the study offers an analysis of the objectives of the migration containment policies in the international relations between Italy and Libya, as well as their current extension to other African countries and regions, also examining the effectiveness of these policies.
\end{abstract}

Keywords: migration, Libya, Qadhafi, Mediterranean, Italy

Since the late 1990s, Libya has become a privileged destination for important international migration flows from other Arab states, from different countries in Africa to the South of the Sahara, and even from Asian countries such as Bangladesh, India and China. Since the Libyan situation is complex, rapidly evolving and not always easy to study due to the difficult conditions of access to the country, the international press have often focused on the issue of illegal migrants who embark from Libya and head for Italy and the rest of Europe. For this reason, Libya has often been seen as a transit country, despite the objective fact that "most migrants remained in Libya"2 when Mu'ammar al-Qadhafi was in power, and for the most part continued to remain there even after the fall of his regime in 2011, despite the rapid increase in landings on the Italian coasts. ${ }^{3}$ There is no doubt that the dynamics of the conflict have opened up unimaginable opportunities of manoeuvre for the criminal networks that manage trans-Mediterranean migration. On the other hand, the country's

This publication was written in commission of the National University of Public Service under the priority project PADOP-2.1.2-CCHOP-15-2016-00001 entitled "Public Service Development Establishing Good Governance" in the framework of Africa in the Globalized World Ludovika Research Group.

2 Paoletti, Emanuela - Pastore, Ferruccio: Sharing the dirty job on the southern front? Italian Libyan relations on migration and their impact on the European Union, [online], IMI Working Papers Series, 29.12.2010, p. 11. Source: International Migration Institute [15.09.2017.]

3 More than one filed research confirm that point: Danish Refugee Council (DRC): "We risk our lives for our daily bread". Finding of the Danish Refugee Council Study on mixed migration in Libya, [online], December 2013. Source: DRC

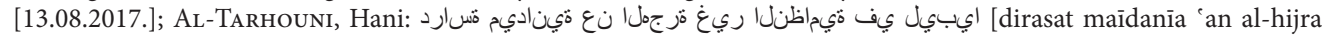
ghīr al-nizamīata fi libia: Field Study of Irregular Migration in Libya]. Libyan Affairs, No. 1, 2016, pp. 36-46; Morone, Antonio M.: Policies, Practices, and Representations Regarding Sub-Saharan Migrants in Libya: From the Partnership with Italy to the Post-Qadhafi Era. In: Gaibazzi, Paolo - Dünnwald, Stephan - Bellagamba, Alice (eds.): EuroAfrican Borders and Migration Management. Political Cultures, Contested Spaces, and Ordinary Lives. Palgrave Macmillan, New York, 2017, pp. 129-155. 
economy, though increasingly dependent on a predatory logic linked to the society's institutional fragility and factionalism, continued to grow at a rate of $116 \%$ in 2012, according to International Monetary Fund data. ${ }^{4}$ Post-Qadhafi Libya has thus continued to attract cheap labour from both sub-Saharan countries and other Asian or Mediterranean Arab countries.

Therefore, between 2011 and 2014 a situation came about in which the conflict in Libya increased both human mobility to Europe and continued to stimulate human mobility from neighbouring countries, and subsequently from sub-Saharan Africa, towards Libya. These were not two distinct processes, but were interconnected, since residence and work in Libya for a more or less lengthy period often determines the basis of selection between a first migration towards Libya and a second one to Europe. Exception is made for those migrants determined to seek political asylum or humanitarian protection in Europe from the start of their migratory project, as for example Somalis and Eritreans. In these cases, migrants move along networks well-structured and well-financed by friends, relatives or simple fellow countrymen already resident in Europe, especially in Northern Europe, who invest in a relatively rapid journey of their loved ones or acquaintances by identifying Libya as the most favourable illegal passage for reaching Europe. In many other instances, surely the majority, migrants headed for Libya have neither a predetermined migration project nor even readily available resources, so that it is usually during their work period in Libya that they come to the decision of trying to cross the Mediterranean, based mainly on the resources and opportunities at their disposal. They may instead decide to extend their residence in Libya or undertake a successful return migration if they have succeeded in saving enough money to meet their prior expectations or, if this would fail, take stock of the failure of their migration project. From the summer of 2014 to today, the dynamics of the conflict have grown exponentially, causing the fragmentation and multiplication of the last remaining national institutions and generating an economic and banking crisis that has rapidly impoverished a large sector of the population. In this new situation, perhaps the balance between the different migratory paths has been further modified in favour of an increase in departures to Italy and the rest of Europe.

Because of this complex migratory situation, over the past three decades Libya has been a true laboratory for European and especially Italian migration policies. The years from the 1990s until the present have been characterised by two conflicting tendencies in Libya: on the one hand, the policies of the Qadhafi regime, characterised by an opendoor policy towards the influx of low-cost labour from sub-Saharan Africa and the Arab countries; on the other hand, the containment policies put in place by Italy to halt illegal migration flows through the Mediterranean Sea, which were however an infinitely small proportion of the total number of migrants in Libya. Italian-Libyan bilateral relations were thus much characterised by the restrictions Libya imposed over the migration flows, which Italy requited with its commitment to support the end of the international embargo

4 Sт. John, Ronald B.: The Post-Qadhafi Economy. In: PAск, Jason (ed.): The 2011 Libyan Uprisings and the Struggle for the Post-Qadhafi Future. Palgrave Macmillan, New York, 2013, p. 106. 
on Libya and its readmission to the international community. ${ }^{5}$ With the collapse of the regime in 2011 and the beginning of the civil war, a new phase opened up in which the very distinction between legal and illegal migrants has progressively lost meaning, inasmuch as the weakness, if not the actual disintegration of Libyan institutions, has led informality to prevail over the rule of law. Italy and, increasingly, the rest of Europe have continued to exert a series of direct and indirect pressures on the new Libyan authorities with the aim of reaffirming the policies of migratory containment, but political instability and the persistence of conflict have strongly compromised the effectiveness of this attempt, urging rather a further extension of containment policies to other African countries to the South of Libya, from which migrants leave or transit. This study aims at analysing the objectives of the containment policies of migration flows in the international relations between Italy and Libya, as well as their current extension to other African countries and regions, also examining the effectiveness of these policies.

\section{Qadhafi bargaining with Italy}

During the 1990s, Qadhafi's foreign policy progressively veered away from Pan-Arabism toward Pan-Africanism, with the idea of making Libya a regional power on the African continent, and especially in the process of reforming the Organization of African Unity (OAU), which culminated in the creation of the new African Union (AU) at the Durban Summit in South Africa in 2002. Libya was actually one of the most committed countries to promote the reform of the continental African organisation, supporting it with both a lavish international cooperation program, financed by Libya's oil revenues, and by opening up the Libyan labour market to cheap labour from abroad. Qadhafi had already opened Libya's borders to foreign workers in 1998 by promoting the creation of the organisation of Sahel-Saharan States, which established among the participating countries (soon all the North African countries and those of Sahel-Saharan Africa, with the exceptions of Algeria and Ethiopia) a vast area of free trade and free movement of workers. In 2002, the same year as the new AU was founded, Qadhafi launched what was called Libya's development program through African labour, literally opening Libyas Southern border to foreign workers, who could not only gain access to the country solely with passports and in some cases with a simple national identity document, but could also find work without being obliged to submit to formal contractual, trade union and insurance regulations. Obviously, this arrangement substantially prefigured the exploitation of foreign labour in the absence of the minimal protection of workers' rights, but for many poor or very poor migrants the chance to easily find a relatively well-paid job in Libya became a very attractive factor, such as to stimulate very considerable migration flows. Over the new millennium the number of legal migrants grew rapidly in Libya, reaching $10.4 \%$ of the Libyan population in 2010, and estimated at 6.5 million people, while the number of illegal migrants ranged from 1.5 to 2 million people. ${ }^{6}$

Paoletti, Emanuela: The Migration of Power and North-South Inequalities: The Case of Italy and Libya. Palgrave Macmillan, Basingstoke, 2011.

6 MCP migration profile: Libya, [online], June 2013. Source: migrationpolicycentre.eu [13.08.2017.] 
Libya's open door to international migrants was accompanied, as a reaction, by the progressive creation of policies promoted by Italy to contain illegal migration across the Mediterranean. While the numbers of migrants directed towards Europe were relatively small in relation to the total number of those in Libya, ${ }^{7}$ the political need for Italy to control the flows transformed irregular migrants into a bargaining chip in Italian and European relations with Libya. On December 13, 2000, Italy signed an agreement with Libya to cooperate against terrorism, drug trafficking and irregular migration. This agreement was the basis for the subsequent secret and never publicised agreement of 2003, on the basis of which Italian patrols could enter Libyan waters and Italian police were sent to Libyan ports, while Tripoli obtained military means and materiel to control its borders. According to this 2003 agreement, Libya was also willing to readmit irregular migrants that arrived in Italy. In 2004 and 2005 Italy intensified its collective repatriation activities, which were actual deportations, despite the condemnations of the European Parliament and the European Court of Human Rights. In reality, Italian operations were not particularly contested since, although the European Parliament's 2005 condemnation was indisputable, "the European Commission took refuge in its lack of jurisdiction over the matter" ${ }^{8}$ In 2007, a Memorandum of Understanding was signed between the Italian Minister of the Interior and his Libyan counterpart, which established, at least in theory, Italian Navy patrol units with mixed crews in Libyan territorial waters, with the intention of halting migrant sea craft. The 2007 agreement finally became operative in 2009, following ratification by the Italian Parliament of the Treaty of Friendship, Partnership and Cooperation between Italy and Libya, signed in 2008. The Treaty marked a historic step in the relations between the two countries owing to Italy's excuses for colonial crimes, but they ended up being "mendacious" because they functioned "as a mutual cover of the two leaders before their respective public opinion" for quite different interests. ${ }^{9}$ It was Berlusconi who on his return from Benghazi triumphantly announced to the Italian press that the Treaty would soon mean "fewer illegal migrants and more gas and oil." ${ }^{10}$ Beyond the manifest inconsistency of the colonial history in the present Italian discourse over the national past and memories, ${ }^{11}$ the 2008 Treaty paved the way for those Italian-Libyan joint patrol activities and the so-called push-back strategy in order to halt migrants at sea and to forcibly bring them back to Libya. In a few months, landings on Italy's coasts thus nearly ground to a halt.

The refoulement of those migrants, which in 2008 was presented by the Italian Ministry of the Interior as the most effective means of "international co-operation on illegal immigration and the traffic in human beings," 12 actually undermined the rights of migrants in

The average annual arrivals on the Italian coasts during the 2000 s amounted to about 26,000 people, considering not only arrivals from Libya, but also those from other routes, such as Tunisian and Egyptian ones. The data are derived from PAPAVERo, Giorgia: Sbarchi, richiedenti asilo e presenze irregolari, February 2015. p. 6. Source: ismu.org [31.07.2017.]

8 Perrin, Delphine: Fin de régime et migrations en Libye. Les enseignements juridiques d'un pays en feu. L’Année du Maghreb, No. 7, 2011, p. 297.

9 LabAncA, Nicola: La guerra di Libia nelle pubblicazioni e negli studi italiani degli ultimi venticinque anni. I Sentieri della Ricerca, No. 13, 2011, p. 42.

10 Di Carlo, Paola: Berlusconi, patto con Gheddafi «Ora meno clandestini e più gas». Corriere della Sera, 31.08.2008.

11 Morone, Antonio M.: Asimmetrie postcoloniali: le relazioni italo-libiche tra storia e memoria. In: SinOPOLI, Franca (ed.): Postcoloniale italiano. Tra letteratura e storia. Novalogos, Roma, 2013, pp. 174-187.

12 Iniziative dell'Italia. Sicurezza, immigrazione e asilo, [online], 02.02.2010, p. 17. Source: Interno.int [04.09.2017.] 
their ability to seek asylum or humanitarian protection in Italy, and constituted an exception to the rule of law, with the result that Italy was found guilty of such acts on June 6, 2012 by the judges of the European Court of Human Rights. The judgment in that case referred to the fact that the refoulements at sea did not respect the principle of non-refoulement and prevented potential refugees from applying for asylum. ${ }^{13}$ The international ruling revealed all of Italy's hypocrisy in accusing Qadhafi of never having signed the 1951 United Nations Convention on the Status of Refugees and failing to respect the human rights of migrants, when it was really Italy that shoved onto Libya the task of receiving, accepting and assessing any right to asylum or protection of those who were turned back at sea. On the other hand, Qadhafi himself left no room for doubt on this point when, shortly after signing the 2008 Treaty, he proceeded to shut down the offices of the United Nations High Commissioner for Refugees, which until then had operated in his country without any official recognition, precisely because Libya was not a signatory to the 1951 Convention. Qadhafi left no alibi to his European partners over the fact that it was entirely up to them to address the question of protecting migrants' rights, since the very concept of human rights was not recognised by the theory of the Libyan Revolution, which "did not guarantee civil and political rights because it did not recognize the concept of citizenship."14

The push-back strategy was founded as a safeguard mechanism of the Mediterranean Sea and as a process of externalising the Southern border between Italy and the EU onto Libyan soil, which represented a real qualitative leap in the various rejection policies until then conceived and implemented in North-South relations in the Mediterranean region. From the 1990s, Italy promoted a migration diplomacy aimed at enacting a number of agreements with several Mediterranean states, not only Libya, with the objective of countering irregular migrant flows. In 1998, the Italian-Tunisian agreement, which entered into force the following year, was signed, on the basis of which Italy offered Tunisia for the three-year period (1999-2001) the sum of 20 million Euros (further integrated with cooperation funds) to finance the technology for controlling its borders, ${ }^{15}$ and Tunisia in turn committed itself to a readmission clause. Also, in 1998, a similar readmission agreement was signed with Morocco. In 1999, Italy signed a police cooperation agreement with Algeria and in 2000 one on readmission. In 2000, Italy concluded another treaty with Egypt, which provided for close cooperation in policing, and specifically aimed at controlling the irregular migration flows through the Suez Canal and by ship from India, Pakistan and Sri Lanka. In this instance too, cooperation on security was linked to a readmission clause signed in $2007 .{ }^{16}$

13 Conseil de l'Europe, Secrétariat Général: Plans d'action du Gouvernement italien dans l'affaire Hirsi Jamaa et autres c. Italie, requête no. 27765/09, réunion $1150 \mathrm{DH}, 06.07 .2012$.

14 Baldinetti, Anna: Le istanze amazigh in Libia: la nascita di una società civile? In: Maneggia, Amina (ed.): Processi politici nel Mediterraneo: dinamiche e prospettive. Morlacchi Editore, Perugia, 2009, p. 232.

15 Cuttitta, Paolo: I confini d'Europa a Sud del Mediterraneo. Strumenti e incentivi per l'esternalizzazione dei controlli. In: Vassallo Paleologo, Fulvio (ed.): Migrazioni, frontiere, diritti. Edizioni Scientifiche Italiane, Napoli, 2006, pp. $16-17$.

16 Ibid. 18. 
The instruments of international cooperation varied according to the circumstances: joint security activities between the Italian police and partner countries, the provision of means and technology, the willingness to readmit irregular migrants, whether individually or collectively. However, only in the case of Libya was an Italian operation established on the territory of the partner state, in cooperation with Libyan police. Libya was in fact willing to accept what other Arab countries refused, judging it as an act affecting its national sovereignty, namely the construction of camps and the implementation of policies involving the presence of Italian officials operating on foreign soil. The reasons that may explain Libya's willingness to cooperate so thoroughly with Italy can surely be found in the importance of the trade-off that the agreement provided for Libya, but probably what also counted was the fact that, unlike Tunisia and Egypt, migrants included in the containment policies were third country nationals, certainly not Libyans, while in case of agreements negotiated by Italy with Tunisia and Egypt, an important part of the migrants concerned were citizens of those countries, Tunisians and Egyptians. The fact that it was obviously a matter for third country nationals eased the Libyan authorities of any possible rebound in terms of internal political dissent. On the contrary, a public backlash to the massive immigration from sub-Saharan Africa grew in Libya in the 2000s, reproducing a series of stereotypes similar to those that characterise certain attitudes about migration in Europe, where racist ideas combine with nationalist identity memes: from stereotypes that migrants are dangerous criminals to those that see them as responsible for the spread of infectious diseases, to their hypothetical role played in the "Africanisation" of a country such as Libya, centred on its identity as an Arab, Islamic nation. In this context, it is understandable that the policies in question did not give rise to Libyan popular opposition because they did not concern Libyans, but foreigners, while found a certain favour in some segments of the public opinion often disoriented by, if not openly hostile to, such large numbers of migrants.

The containment policies described were not only aimed at controlling the flows in the Mediterranean Sea, but also had a series of direct and indirect effects on Libyan territory. One point was that, as a result of Italian pressures, Libya proceeded to review at least part of its open door policy towards sub-Saharan workers by introducing a tighter regulation of entry visas, with the exception of Maghrebis, obliging foreign workers to obtain compulsory insurance, and work and residence permits in Libya, as well as introducing into law the offense of illegal immigration, punishable by up to three years of imprisonment. We can conclude about Libya what has already been said about the introduction of the crime of illegal immigration in Tunisia and Morocco, that this offense responds primarily to requirements associated "with illegal immigration into Europe"17 and produces a great tendency to criminalise migration. The combined effect of these measures was to transform over a short period of time a mass of foreign workers who had free access to the country into irregular migrants, with the result of increasing their vulnerability and likelihood of

17 Perrin, Delphine: Immigration et création juridique au Maghreb. La fragmentation des mondes et des droits. In: BensAad, Ali (ed.): Le Maghreb à lépreuve des migrations subsahariennes. Immigration sur émigration. Karthala, Paris, 2009, p. 251. 
being exploited, complying at the same time with Italy's demands for a stricter legislative discipline regarding international migration. ${ }^{18}$

The second point was that, since 2004, under the Italian-Libyan cooperation framework, the Italian Government made available the funds and technical means needed to build transit camps that were de facto internment centres, actual prisons where irregular immigrants were detained while waiting to be deported to their countries of origin or to third countries. The main camps for this purpose were built in Cufra and Sebha for a total of 18 or perhaps 19 structures. ${ }^{19}$ The closing of the Mediterranean Sea to the transit of irregular migrants was only one part of the complex mechanism of containment of the flows agreed on by the Italian and Libyan authorities. Once brought back to Libya, with the help of Italian officials in Tripoli, the migrants were sent to the camps, along with other irregular migrants arrested and imprisoned before attempting to embark from Libya. For all of them, at least in theory, the so-called way to repatriation was opened up in their countries of origin. The appropriateness of the term "repatriation" may justly be called into question as it is often used in official documents, since it presupposes a voluntary decision on the part of the returnee, which appears at the very least hard to believe in a context of imprisonment, exploitation and violence. It would be more fitting to speak of deportation, in a situation of compulsion, than of voluntary decision. In any case, expulsion from Libya ended up taking on the features of a much more undefined event than what the international policies intended.

The so-called repatriations to countries of origin were often very difficult to carry out because of the lack of agreements between Libya and the governments of these countries, and ultimately because of the lack of mutual political interest. Qadhafi's Pan-African policy presupposed good relations with many of the governments of which the migrants were citizens. Recognising their demands for political asylum or expelling them from Libya threatened to compromise these relations because in the first case the legitimacy of the partner State's government would have been called into question, and in the second case such a strategic resource as the migrants' remittances to their States of origin would have been limited. There were also extreme cases where so-called repatriation was not possible because of the state of war and conflict of the country of origin, as in Somalia. In the absence of well-defined political agreements and political interests, many deportees simply ended up being taken over the Southern Libyan border into Niger, where the vast majority found themselves in another foreign country and subjected to new forms of exploitation and violence.

18 Drozdz, Martine - Pliez, Olivier: Entre Libye et Soudan: la fermeture d'une piste transsaharienne. Autrepart, Vol. 36, No. 4, 2005, p. 69.

19 Ceccorulli, Michela: The Mediterranean as a Buffer. Confining Irregular Migrant in North Africa. In: CecCorulli, Michela - Labanca, Nicola (eds.): The EU, Migration and the Politics of Administrative Detention. Routledge, Abingdon, New York, 2014, p. 196. 


\section{Continuity in post-Qadhafi containment policies}

The fall of the Qadhafi regime in 2011, and the beginning of the civil war that still divides the country today immediately caused the collapse of the control system of irregular flows that had been in force during the previous ten years of collaboration between Italy and Libya. The direct consequence was a large-scale migration crisis that, according to the United Nations High Commission for Refugees, involved over 750,000 third country nationals only in the first few months of the war, from February to May 2011, in addition to more than 100,000 Libyans who sought refuge in Egypt and 150,000 in Tunisia. ${ }^{20}$ Within a year, with the end of the NATO-led international military operations and the waning of the conflict in the country, Libya quickly returned to attracting sizeable flows from neighbouring countries, especially from Africa, South of the Sahara, since work in the country was not lacking and Libya continued to entice aspiring immigrants more with the idea of a country where it was relatively easy to realise their hopes of social mobility rather than a country at war where their lives could be endangered.

According to one of the most recent qualitative field surveys, carried out in 2015 by a Libyan government research centre, the National Economic and Social Development Board, most of the migrants interviewed, $40.3 \%$ said they wanted to stay in Libya to find work, which for $36 \%$ could be just unskilled day labour, despite the fact that since the summer of 2014 the country's conflict had rapidly increased; $37 \%$ of the sample said they were ready to go to Europe, while the remaining $22.7 \%$ had no precise plan. ${ }^{21}$ Other investigations carried out earlier, prior to the resumption of the war, indicated that in 2014 only $15 \%$ of another sample of migrants declared that they wanted to leave for Europe, and even less according to data from another survey conducted between 2012 and 2013. ${ }^{22}$ Overall, it can be said that the landings on Italian coasts have been growing rapidly in the last few years, from an average of 30 to 35 thousand people at the beginning of the decade to more than 180,000 people in 2016 and 86,000 in the first semester of $2017 .{ }^{23}$ However, this is still a very small part of the entire flow present in Libya. Moreover, it is extremely indicative that, on the basis of European data, of the 929,000 migrants, all of whom entered Europe in 2015 , only $16 \%(154,000)$ of them used Libya as the starting point for crossing the Mediterranean, registering a $9 \%$ reduction compared to the previous year, attributable to a better security situation in Egypt and to a greater difficulty of entering Libya. ${ }^{24}$

However, the Italian and European policy decisions of recent years have not been based on a careful, well thought out assessment of the figures, but rather on an often hasty,

20 Humanitarian Situation in Libya and the Neighboring Countries, [online], 10.05.2011. Source: UNHCR Update [11.09.2017.]

${ }^{21}$ Other data found that $23 \%$ of the sample were illiterate, $24.5 \%$ had a high school diploma and $4 \%$ a degree. In $30 \%$ of the cases, migrants already had relatives or close friends in Libya when they travelled to the country. Often those who leave their country have committed non-condonable or recompensable crimes and others have been convicted by a court. Al-Tarhouni (2016): op. cit.

22 Respectively, Danish Refugee Council (DRC): “We risk our lives...” (2013), p. 19; Morone (2017): op. cit. 151.

23 Statistiche del Ministero dell'Interno, [online], 13.07.2017. Source: Ministero dell'Interno [07.31.2017.]

24 EUNAVFOR MED: Operation Sophia, six monthly report, June, 22nd to December, 31st 2015, from Rear Admiral, Italian Navy, Operation Sophia Commander Enrico Credendino to Chairman of the Political and Security Committee, Ambassador Walter Stevens, [online], 2016. Source: Wikileaks.org [31.07.2107.] 
precipitous reaction to emergency situations. In this fashion, Italy undertook to renegotiate containment policies with the Libyan authorities. On January 21, 2012, the Minister of the Interior, Annamaria Cancellieri, on a visit to Tripoli, signed a Memorandum with the Libyan counterpart, expressing the intention to renew cooperation for training the Libyan Police and Coast Guard, building infrastructures aimed at containing migrants, coordinating programs for repatriating migrants to their countries of origin, and bolstering joint border control. ${ }^{25}$ It was in fact a direct return to the past, even though Mario Monti's government was forced to officially announce on June 20, 2012 that it was giving up turning back migrants on the high seas as a means of flow control, following the sentence imposed on Italy by the European judges. ${ }^{26}$ In spite of everything, a second Italian-Libyan agreement, signed on February 2, 2017, opened the way to new refoulement operations at sea, though this time executed autonomously by the Libyan Coast Guard thanks to Italy's training and materiel. Thus, Italy guarded itself against a new condemnation by the European judges by ceasing to participate actively in refoulements, but in substance it has not changed much. In addition, the agreement reaffirms the will to cooperate in managing "temporary hosting camps" in Libya, which must serve to repatriate migrants. ${ }^{27}$

Italy's attempt to reactivate the process of externalising the control of migrant flows has been an all-round strategy not only for controlling departures but also for resuming deportation operations to countries of origin or third countries. According to figures published by Amnesty International, between May 2012 and April 2013, at least 25,000 people were taken to the southern border of Libya near Gatron. ${ }^{28}$ Also based on my own data recorded in 2014 in Khums, 110 kilometres on the East coast of Tripoli, at the end of 2012 Libyan authorities began working to resume control of migratory flows in the region, monitoring the camps and the various detention facilities. In addition, in 2013, under international pressure, the Department for Combating Illegal Migration (DCIM) was set up within the Libyan Interior Ministry, which was able in a short time to bring under the control of Tripoli, at least nominally, a number of camps and prisons for more or less informal migrants, in addition to coordinating migration control and deportation activities. In a context such as Libya's, where the State and its institutions have been and are still going through a period of particular weakness and fragility, the DCIM contradicts the stereotype of a failed state and highlights the enormous influence that foreign players, such as that exerted by Italy, the EU and other international agencies, can have on the Libyan situation. It is obvious that the picture described proposes a political trade-off very similar to the one Italy negotiated with Qadhafi: the willingness of Libya to participate in controlling migrant flows in exchange for international recognition, which for the new Libyan authorities promises to be still more important than it was for the Qadhafi regime.

Conflict, institutional fragility and political instability in Libya have, however, greatly reduced the effectiveness of joint containment policies with Italy. For this reason, the Italian

\footnotetext{
25 The Hounding of Migrants Must Stop, [online], 2012, p. 36. Source: FIDH (International Federation for Human Rights) [28.07.2017.]

26 Immigrazione: Libia; Terzi, respingimenti non in agenda governo, [online], 20.06.2012. Source: ANSAmed [23.07.2017.]

27 UselLI, Sandra: Italy-Libya agreement, the Memorandum text, [online], 07.02.2017. Source: ASGI [05.09.2017.]

28 Amnesty International: Scapegoats of Fear. Rights of Refugees, Asylum-Seekers and Migrants Abuses in Libya, [online], 2013, p. 6. Source: Amnesty.org [13.09.2017.]
} 
authorities, in increasingly close coordination with those at the European level, have sought to control flows in the Mediterranean Sea or still better throughout the Sahel-Saharan region of Southern Libya, with the stated intention of blocking migrants before they arrive in Libya and from there to Italy and the rest of Europe. Through Operation Mare Nostrum, the Italian Navy patrolled the waters of the Central Mediterranean from October 2013 to December 2014, escorting migrants to Libyan territorial waters, an operation that marked a change in Italian policy from refoulement to rescue at sea. The change marked by Mare Nostrum was actually "more quantitative than qualitative", 29 in that the actions taken were "not much more humanitarian than the previous patrol activities carried out in the Sicilian Channel", 30 so much so that the objective still remains that of repatriating migrants after having rescued them at sea, except for those recognised as political asylum seekers or in need of humanitarian protection. From the fall of 2014, the Italian naval mission has been gradually replaced by a new naval operation called Triton, under the direction of the European Border Control Agency (FRONTEX).

Triton's operations have been considerably smaller than the Italian mission and were actually conducted out of Libyan territorial waters after a series of accusations were made against the command of Mare Nostrum because, by operating inshore in Libyan territorial waters, it would have the perverse effect of encouraging emigration. If it cannot be totally ruled out that such an effect at least in part took place, it is undeniable that the main factor of the rising flows from the Libyan coast is to be attributed to the exponential growth of the criminal activities of the migrant trafficking networks throughout the Mediterranean, and therefore a reduction of rescue operations at sea has resulted above all in an increase of deaths at sea, not in a reduction of departures. It was precisely to strike a blow against those networks, infrastructures and traffickers in human beings over the Mediterranean, that a second European naval mission called "European Union Naval Force Mediterranean" (EUNAVFOR Med) was launched in April 2015 due to a substantial contribution from Italy and other European navies. From a confidential 2015 report of the commander of what is now called Operation Sophia, the goal was to dismantle a business that earned annually between 250 and 300 million Euros. At the same time, the joint command of Operation Sophia was aspiring to intervene in Libyan territorial waters on invitation by the Libyan Government of National Accord, as well as to recover the control at sea by "strengthening the operational capabilities of the Libyan Navy and the Coast Guard", namely training Libyans in compliance with the February 2017 agreement. $^{31}$

In the parabola of the various policies and operations undertaken to control migratory flows across the Mediterranean, it is evident that Italy has successfully sought a progressive involvement of the European Union, with the result of Europeanising its strategy of containing migratory flows, which, by penetrating throughout Europe, have sorely stressed the "Schengen area". The growing internal EU bickering between Member States sharing

\footnotetext{
29 Cuttitta, Paolo: Mare Nostrum e la retorica umanitaria. Rivista di Storia delle Idee, No. 4, 2015, p. 133.

30 Cuttitta, Paolo: From the Cap Anamur to Mare Nostrum: Humanitarianism and Migration Controls at the EU's Maritime Borders. In: Matera, Claudio - TAylor, Amanda (eds.): The Common European Asylum System and Human Rights: Enhancing Protection in Times of Emergencies. The Hague, CLEER Working Papers, No. 7, 2014, p. 36.

31 EUNAVFOR MED: Operation Sophia... (2016).
} 
the burden of hosting migrants has rapidly prompted the EU not only to increase its control of external borders, but also to make a greater commitment to a range of policies aimed at containing flows even before they reach the Union's borders. During Italy's six-month presidency of the EU, it promoted the Khartoum Summit in Sudan, from October 13 to 16, 2014, which launched the EU-Horn of Africa Migration Route Initiative, then officially baptised on November 27 and 28 during the $4^{\text {th }}$ Euro-African Ministerial Conference held in Rome. With what is known colloquially as the "Khartoum Process", Italy and the EU, as stated in the Final Declaration of the Conference, aimed at "improving national capabilities" of transit countries in "migration control" and ultimately to extend or strengthen the means of flow control already proven effective in the Mediterranean area, especially in countries considered to be of strategic importance, such as Niger, Sudan, Ethiopia and Eritrea. ${ }^{32}$ Once again, migration became first and foremost an issue of security policies and produced a demand for control over irregular migration rather than focusing on policies of legal access to European territory, reforming for instance visa policy, facilitating remittances or opening humanitarian corridors. The Khartoum Process was indeed moving in the context of further externalising of migration flows to the South, replicating policies and strategies implemented in Libya. In addition to the police and readmission agreements, specific reference was made to the creation of "reception and government centres" that were to be opened on the basis of "an individual and voluntary request of a country in the region", with the aim of controlling flows and identifying migrants entitled to seek political asylum in Europe. ${ }^{33}$

In this context of extremely rapid expansion of containment policies from the Mediterranean region to entire regions of the African continent, what was traditionally defined as cooperation for development has been taking on an increasingly migratory connotation. In case of Libya, the trade-off for the control of flows has been and continues to be purely political, since Libya, as a relatively rich country with its own ambitious international cooperation program, clearly did not need European aid. On the contrary, in relations with its new African partners, in addition to international recognition, which is certainly a very important asset for countries that have for years been regarded as authoritarian regimes and condemned for this by the West, as in the case of Sudan and Eritrea, even development aid takes on an aspect of prime importance. In recent years, cooperation for development has become increasingly subordinated to conditions regarding migration, which have taken precedence over those related to respect for human rights. In the European summit held at Valletta on November 12, 2015, an Emergency Trust Fund was set up for Africa, which allocated an initial budget of 2.8 billion Euros in development cooperation projects directly or indirectly related to the issues of migration flows, policies of containment and those of "reintegrating" migrants who are repatriated from Europe or from other third countries. The Italian contribution to an all-round externalising in Africa has been reaffirmed by the so-called Migration Compact. Contribution to an EU strategy

\footnotetext{
32 Rome Declaration: Declaration of the Ministerial Conference of the Khartoum Process, EU-Horn of Africa Migration Route Initiative, [online], 28.11.2014. Source: Italia2014.eu [30.08.2017.]

33 Ibid.
} 
for external action on migration, made public on April 15, 2016, ${ }^{34}$ which was followed by more substantial bilateral funding from the Italian Cooperation to countries such as Niger, Nigeria, Ethiopia and Eritrea. There is a glaring contradiction to granting strategic aid to governments such as those of Sudan or Eritrea, to give just two examples, which according to the parameters of conditioning cooperation to respect human rights had been excluded in the past, or greatly reduced from participation in development programs; today, in order to obtain the willingness of such countries to cooperate in the policy of containment, we stoop to compromising on respect for human rights at the very moment when we would like to affirm that the protection of migrants' rights is a priority. Thus policy risks becoming unsustainable if it asks governments recognised internationally as guilty of serious violations of human rights to protect the rights of migrants, to recognise their possible status of applicants for asylum or international protection, defining them illegitimately as "safe countries" not on the basis of an objective reality, but simply because of their willingness to cooperate in preventing the human mobility of their nationals or those of third countries.

\section{Are containment policies really working?}

To conclude this overview from the 1990s to the present, for almost thirty years countries of the geopolitical North of the world, such as Italy, have planned, contracted and implemented several containment measures and policies with many countries in the geopolitical South of the world, such as Libya. Libya has been a laboratory not only for experimenting with such measures and policies but also for exporting them to other African countries. If the goal of these containment policies was to prevent as many migrants as possible from entering Italy and the rest of Europe, then it is precisely the constantly increasing numbers of migrants that point to the limited effectiveness of such policies. If the objective was, more reasonably, to distinguish migrants eligible for humanitarian protection or political asylum from everyone else, allowing Europe-wide access to the former and strongly restricting it for everyone else, in this case too, the results risk being modest, since the concept of containment is being mixed up with that of "preventive protection". In this regard, it should be emphasised that by identifying countries that are considered safe, often without any objective reality, in the end we worry more about guaranteeing not so much the right to leave, but rather to remain and be protected on site, safeguarding the security of the potential refugees rather than their rights. The result may be very negative in terms of a new concept of refoulement, called neo-refoulement or preventive refoulement, which makes it possible to circumvent the prohibition of refoulement sanctioned by the 1951 Convention of Refugee Rights, by returning asylum seekers or other migrants to transit countries or to their regions of origin, before they reach the sovereign territory in which they could make their request. ${ }^{35}$ The case of Libya is excellent proof of how migrants eligible to seek asylum or protection have for years been deprived of this possibility as a result

34 Migration Compact. Contribution to an EU strategy for external action on migration, [online], 2016. Source: Governo.it [30.08.2017.]

35 Hyndman, Jennifer - Mountz, Alison: Another Brick in the Wall? Neo-Refoulement and the Externalization of Asylum by Australia and Europe. Government and Opposition, Vol. 43, No. 2, 2008, p. 250. 
of containment policies. What containment policies have undoubtedly given rise to, as effectively as contradictorily, has been the flow of irregular migrations.

In this regard, there was an illuminating intervention by Mohamed Karwad, a Libyan official representing the Government of National Accord, during a forum on migrations hosted in April 2016 in Tunis by the Center Maghrébin d'Études sur la Libye (CMEL). Karwad confirmed the full resumption of deportation policies outside Libya starting in 2013, and the transition from ground to air operations for "the many crimes against migrants that took place on land". ${ }^{36}$ According to the figures he reported, there have been at least 100,000 refouled migrants over the past 3 years to several African countries, including Eritrea, where irregular migration is equated with desertion and is punishable with incarceration and forced labour or even capital punishment. He concluded provocatively that "we ship these people to Niger, but after fifteen days they return with another 20 people because, having already made the trip once, they now know the tracks and become themselves passeurs for other migrants who have never been to Libya". ${ }^{37}$ Thus it is not just a matter of questioning those often abused categories that distinguish too neatly between "criminal traffickers" and "exploited migrants", but mainly of admitting the contradictoriness of those policies by which these very categories are produced and packaged, and more generally, of reflecting critically on the abusiveness of containment policies and their consequences as exceptions to the Rule of Law. ${ }^{38}$ If what moves a substantial number of international migrants, probably most of them, are legitimate aspirations of social mobility and not violations of human rights, then it must be concluded that the rhetoric of international humanitarian protection is in practice intended to hinder, and if possible to halt, a much more "normal" mobility associated with the aspirations of individuals to improve their social status through a migratory project founded on positive representations of the Western world, imagined and idealised through globalisation.

\section{REFERENCES}

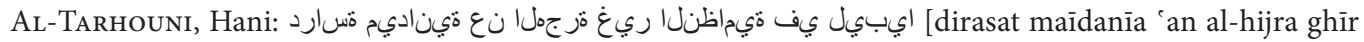
al-nizamiata fi libia: Field Study of Irregular Migration in Libya]. Libyan Affairs, No. 1, 2016, pp. 36-46.

Amnesty International: Scapegoats of Fear. Rights of Refugees, Asylum-Seekers and Migrants Abuses in Libya, [online], 2013. Source: Amnesty.org [13.09.2017.]

Augusti, Eliana - Morone, Antonio M. - Pifferi, Michele: Il controllo dello straniero. I "campi" dall'Ottocento a oggi. Viella, Rome, 2017.

BAldinetTi, Anna: Le istanze amazigh in Libia: la nascita di una società civile? In: Maneggia, Amina (ed.): Processi politici nel Mediterraneo: dinamiche e prospettive. Morlacchi Editore, Perugia, 2009, pp. 231-250.

Ceccorulli, Michela: The Mediterranean as a Buffer. Confining Irregular Migrant in North Africa. In: Ceccorulli, Michela - Labanca, Nicola (eds.): The EU, Migration and the Politics of Administrative Detention. Routledge, Abingdon, New York, 2014, pp.187-208. DOI: https://doi.org/10.4324/9781315796284

36 KARWAD, Mohamed: Itinéraires de l'immigration illégale vers la Libye. Paper presented at the international workshop "Les dynamiques de l'immigration du Sahel vers la Libye et de la Libye vers l'Europe: itinéraires et devenir, Centre Maghrébin détudes sur la Libye (Cmel)", Tunis, April 26-27, 2016.

37 Ibid.

38 Augusti, Eliana - Morone, Antonio M. - Pifferi, Michele: Il controllo dello straniero. I "campi" dall'Ottocento a oggi. Viella, Rome, 2017. 
Conseil de l'Europe, Secrétariat Général: Plans d'action du Gouvernement italien dans l'affaire Hirsi Jamaa et autres c. Italie, requête no. 27765/09, réunion 1150 DH, 06.07.2012.

Cuttitta, Paolo: I confini d'Europa a Sud del Mediterraneo. Strumenti e incentivi per l'esternalizzazione dei controlli. In: Vassallo Paleologo, Fulvio (ed.): Migrazioni, frontiere, diritti. Edizioni Scientifiche Italiane, Napoli, 2006, pp. 13-40.

Cuttitta, Paolo: From the Cap Anamur to Mare Nostrum: Humanitarianism and Migration Controls at the EU's Maritime Borders. In: Matera, Claudio - Taylor, Amanda (eds.): The Common European Asylum System and Human Rights: Enhancing Protection in Times of Emergencies. The Hague, CLEER Working Papers, No. 7, 2014, pp. 21-37.

Cuttitta, Paolo: Mare Nostrum e la retorica umanitaria. Rivista di Storia delle Idee, No. 4, 2015.

Danish Refugee Council (DRC): "We risk our lives for our daily bread". Finding of the Danish Refugee Council Study on mixed migration in Libya, [online], December 2013. Source: DRC [13.08.2017.]

Di CARLO, Paola: Berlusconi, patto con Gheddafi «Ora meno clandestini e più gas». Corriere della Sera, 31.08.2008.

Drozdz, Martine - Pliez, Olivier: Entre Libye et Soudan: la fermeture d'une piste transsaharienne. Autrepart, Vol. 36, No. 4, 2005, pp. 63-80. DOI: https://doi.org/10.3917/autr.036.0063

EUNAVFOR MED: Operation Sophia, six monthly report, June, 22nd to December, 31st 2015, from Rear Admiral, Italian Navy, Operation Sophia Commander Enrico Credendino to Chairman of the Political and Security Committee, Ambassador Walter Stevens, [online], 2016. Source: Wikileaks.org [31.07.2107.]

Humanitarian Situation in Libya and the Neighboring Countries, [online], 10.05.2011. Source: UNHCR Update [11.09.2017.]

Hyndman, Jennifer - Mountz, Alison: Another Brick in the Wall? Neo-Refoulement and the Externalization of Asylum by Australia and Europe. Government and Opposition, Vol. 43, No. 2, 2008, pp. 249-269. DOI: https://doi.org/10.1111/j.1477-7053.2007.00251.x

Immigrazione: Libia; Terzi, respingimenti non in agenda governo, [online], 20.06.2012. Source: ANSAmed [23.07.2017.]

Iniziative dell'Italia. Sicurezza, immigrazione e asilo, [online], 02.02.2010. Source: Interno.int [04.09.2017.]

KARWAD, Mohamed: Itinéraires de l'immigration illégale vers la Libye. Paper presented at the international workshop "Les dynamiques de l'immigration du Sahel vers la Libye et de la Libye vers l'Europe: itinéraires et devenir, Centre Maghrébin d'études sur la Libye (Cmel)", Tunis, April 26-27, 2016.

LABANCA, Nicola: La guerra di Libia nelle pubblicazioni e negli studi italiani degli ultimi venticinque anni. I Sentieri della Ricerca, No. 13, 2011.

MCP migration profile: Libya, [online], June 2013. Source: migrationpolicycentre.eu [13.08.2017.]

Morone, Antonio M.: Asimmetrie postcoloniali: le relazioni italo-libiche tra storia e memoria. In: Sinopoli, Franca (ed.): Postcoloniale italiano. Tra letteratura e storia. Novalogos, Roma, 2013, pp. 174-187.

Morone, Antonio M.: Policies, Practices, and Representations Regarding Sub-Saharan Migrants in Libya: From the Partnership with Italy to the Post-Qadhafi Era. In: Gaibazzi, Paolo - Dünnwald, Stephan - Bellagamba, Alice (eds.): Euro-African Borders and Migration Management. Political Cultures, Contested Spaces, and Ordinary Lives. Palgrave Macmillan, New York, 2017, pp. 129-155. DOI: https://doi.org/10.1057/978-1-349-94972-4_6

Migration Compact. Contribution to an EU strategy for external action on migration, [online], 2016. Source: Governo.it [30.08.2017.]

Paoletti, Emanuela: The Migration of Power and North-South Inequalities: The Case of Italy and Libya. Palgrave Macmillan, Basingstoke, 2011. DOI: https://doi.org/10.1057/9780230299283

PAOLETTI, Emanuela - PAStore, Ferruccio: Sharing the dirty job on the southern front? Italian Libyan relations on migration and their impact on the European Union, [online], IMI Working Papers Series, 29.12.2010. Source: International Migration Institute [15.09.2017.]

PAPAVERo, Giorgia: Sbarchi, richiedenti asilo e presenze irregolari, [online], February 2015. Source: ismu.org [31.07.2017.]

Perrin, Delphine: Fin de régime et migrations en Libye. Les enseignements juridiques d'un pays en feu. L’Année du Maghreb, No. 7, 2011. DOI: https://doi.org/10.4000/anneemaghreb.1259 
Perrin, Delphine: Immigration et création juridique au Maghreb. La fragmentation des mondes et des droits. In: BensAAD, Ali (ed.): Le Maghreb à lépreuve des migrations subsahariennes. Immigration sur émigration. Karthala, Paris, 2009, pp. 245-265. DOI: https://doi.org/10.3917/kart.bensa.2009.01.0245

Rome Declaration: Declaration of the Ministerial Conference of the Khartoum Process, EU-Horn of Africa Migration Route Initiative, [online], 28.11.2014. Source: Italia2014.eu [30.08.2017.]

Statistiche del Ministero dell'Interno, [online], 13.07.2017. Source: Ministero dell'Interno [07.31.2017.]

ST. John, Ronald B.: The Post-Qadhafi Economy. In: PACK, Jason (ed.): The 2011 Libyan Uprisings and the Struggle for the Post-Qadhafi Future. Palgrave Macmillan, New York, 2013, pp. 85-111. DOI: https://doi. org/10.1057/9781137308092_4

The Hounding of Migrants Must Stop, [online], 2012. Source: FIDH (International Federation for Human Rights) [28.07.2017.]

UsELLI, Sandra: Italy-Libya agreement, the Memorandum text, [online], 07.02.2017. Source: ASGI [05.09.2017.] 